\title{
Social Acceptance of Non-Special Education Lecturers for Students with Hearing Impairment in Lectures of Special Education Study Program
}

\author{
Dewi Ekasari Kusumastuti, Nimas Lintang Ayuning Putri, Eviani Damastuti, Rohmah Ageng Mursita, Mirnawati \\ Special Education Study Program \\ Universitas Lambung Mangkurat \\ Banjarmasin, Indonesia \\ dewi.kusumastuti@ulm.ac.id
}

\begin{abstract}
One thing that plays important role in building inclusive education in universities especially Special Education Study Program is social acceptance of non-special education lecturers for the existence of students with hearing impairment in the lectures. Therefore, the purpose of this study is to know the social acceptance of non-special education lecturers for the existence of students with hearing impairment in lectures of Special Education Study Progam in Universitas Lambung Mangkurat. The method applied in this research was a case study with a qualitative approach. The research subjects were 3 (three) non-special education lecturers that had taught students with special needs in Special Education Study Program of Universitas Lambung Mangkurat. The techniques of collecting data were a questionnaire, interview, and documentation. The data was analyzed by interactive analysis. The results showed that social acceptance of non-special education lecturers for students with hearing impairment in lectures of Special Education Study Program at Lambung Mangkurat University had appeared, but it has not been realized concretely. This is seen from the lack of interaction for students with hearing impairment during learning so that it causes in less understanding of the lecturers about their learning needs.
\end{abstract}

Keywords-social acceptance, non-special education lecturers, hearing impairment.

\section{INTRODUCTION}

Based on Law Number 12 of 2012 concerning higher education which states that education is a conscious and planned effort to realize the learning atmosphere and the learning process so that students actively develop their potential to have religious spiritual strength, self-control, personality, intelligence, noble character, and skills needed by themselves, society and the state [1]. Higher education is a level of education after secondary education which includes diploma programs, undergraduate programs, master programs, doctoral programs, and professional programs, as well as specialist programs held by universities based on Indonesian culture. As it is well known that every citizen has the right to receive education throughout his/her life. This is no exception for citizens of countries with disabilities listed in Law Number 8 of 2016. The right of education for people with disabilities includes the right to get quality education in education units in all types, paths, and levels of education in an inclusive and special manner, have equal opportunities to become educators or education personnel in education units in all types, paths, and levels of education, have equal opportunities as quality education providers in education units in all types, paths, and levels of education, and get eligible accommodation as students.

It is in line with the educational paradigm changing that currently tends to provide opportunities for all children without discrimination, namely inclusive education described in the Minister of Education Regulation No. 70 of 2009 that Inclusive Education is an education system that provides opportunities for all students who have disabilities and have the potential for intelligence and/or special talents to attend education or learning in an educational environment together with students in general. Basically, this is in line with the implementation of higher education which has democratic, principles, and is not discriminatory by upholding human rights, religious values, cultural values, pluralism, unity and national unity [2].

In line with the foregoing, special education and special service education has been regulated in universities in Permenristekdikti Number 46 the Year of 2017 in order to expand opportunities and improve the quality of special education and special service education for students in universities. With this series of policies, it is known that the government is currently trying to pay attention to the fulfillment of the rights of persons with disabilities [3]

One of the efforts made by the government is by promoting the Alignment and Empowerment Program for Students with Special Needs and Disabled Persons by appealing to university leaders not to restrict them from following the admission process for new students in 2017. In the implementation of policies related to students with disabilities, there are of course consequences that must be accepted by universities.

Universitas Lambung Mangkurat is one of the higher education institutions that has implemented the above policy by accepting students with special needs. The students with special needs include 8 students consisting of 5 students with 
hearing impairments, 1 student with physical impairment, 1 student with visual impairment, and 1 student with autism in the Special Education Study Program, Teacher Training and Education Faculty.

In order to succeed in inclusive higher education in accordance with the policies and regulations set out above, the consequences of Higher Education is the obligation to provide services or facilities needed by students with special needs. The services and/or facilities are not limited to physical facilities in the form of buildings or tools. One of the supporting factors for inclusive environmental quality in tertiary education is teaching staff, namely subject lecturers. The thing that is closely related between lecturers and students with special needs is social acceptance between the two. Therefore, this article examines the social acceptance of nonspecial education lecturers who directly face to face with students with special needs. In this case, the researchers focus on the reciprocal process between students who are hearing impaired and lecturers of general or non-special education courses at the Universitas Lambung Mangkurat, Teacher Training, and Education Faculty.

\section{METHOD}

According to [4] qualitative research is research that produces and processes data that are descriptive in nature, such as interviews transcript, field notes, pictures, photos, and video recordings. In this discussion, the type of research used was a case study. According to [5], a case study is a research strategy in which researchers carefully investigate a program, event, activity, process, or group of individuals. Cases are limited by time and activity, and researchers collect information in full by using various data collection procedures based on a predetermined time.

The approach used in this study was a qualitative approach to the type of case study. The selection of a qualitative approach is considered in accordance with the problems to be studied because it aims to find the objective conditions and in a natural setting, and it is expected that with this qualitative approach, the researchers can find out the social acceptance of non-education lecturers specifically for students with special needs in lectures in Special Education courses at Universitas Lambung Mangkurat in-depth and comprehensively using interview or observation techniques involving researchers as core instruments in the field. The subjects in this research are 3 (three) non-special education lecturers that had taught students with special needs of a batch of 2017 in lectures of Special Education Study Program, Universitas Lambung Mangkurat. In addition, the secondary data sources are namely documentation and observation notes. Data collection techniques in this study were interviews, observation, and documentation. This research data analysis was carried out with an interactive model.

\section{RESULT AND DISCUSSION}

Research in [6] reported that most people $(67.85 \%)$ with disabilities choose to work after graduating from high school, while $17.85 \%$ of people with disabilities have been educated, and $3.57 \%$ of people with disabilities plan to work and study.
To be able to realize this plan, students with disabilities must be prepared to live in the world of inclusion, one of which can be started from inclusive education. In addition, students with disabilities must also have preparations related to their needs in competing in the world of work or in college.

Based on this condition, it can be seen that as many as $21.42 \%$ of people with disabilities plan to continue their studies after graduating from high school. Therefore, universities are obliged to accept and accommodate the needs of students with disabilities. One of the important elements in the context of meeting the needs of higher education for people with disabilities is the existence of acceptance from the college environment. The focus of the discussion in this study is the acceptance of special non-education lecturers to students with special needs in lectures in the Special Education Study Program at Universitas Lambung Mangkurat.

Inclusive education will run well if the inclusive pyramid principle is fulfilled properly. The three dimensions in the inclusive pyramid must go hand in hand and cannot be partially implemented. The pyramid is namely inclusive policies, inclusive culture, and real practice [7].

Based on the results of the questionnaires and interviews conducted on three lecturers of general or non-special education courses, namely Civics Education, English, and Introduction to Education, in general, lecturers have had good social acceptance towards students with special needs. However, there are several obstacles experienced during the lecturing process. This study focuses only on lecturers of general subjects to find out social acceptance which includes knowledge, affection, and attitudes carried out on students with hearing impairments during the teaching and learning processes with students with hearing impairments who currently need extra services in receiving the learning process compared to students with other obstacles.

\section{A. Cognitive Aspect}

In terms of knowledge possessed by lecturers in general or non-education courses related to students with hearing impairments, basically, lecturers have known the existence of students with hearing impairments in the classroom. However, the process and time in knowing this matter differed from one lecturer to another. Based on the statement of the lecturer in the general course, it can be seen that the lecturer is aware of the existence of students with hearing impairments through information provided by volunteers who assist them during the learning process in the classroom. There were lecturers who from the beginning of the meeting were aware of the existence of students with hearing impairments. Nevertheless, there were also new lecturers who understand it at the second meeting. This relates to no significant physical differences between students in general and students with hearing impairments.

Basically, after knowing the existence and obstacles experienced by students with hearing impairments, the lecturers knew the needs during the learning process. The needs included the use of sign language/body language and the role of volunteers and clear oral pronunciation in the classroom in delivering material to students with hearing 
impairments. Based on this case, the lecturers invited students with hearing impairments to be able to occupy the first row of seats accompanied by volunteers as many as 2-3 people in the class during the lecture process so that students with hearing impairments so that they clearly hear the pronunciation of the lecturer during the presentation of the material.

In terms of lecturer knowledge about the ability of students with hearing impairments, as the lecture progresses the lecturers began to understand the subject. Aside from the information from the volunteers, there were lecturers who took the initiative to try to find out the condition of the ability of students with hearing impairments through questionnaires that included questions covering the level of hearing ability of students with hearing impairments. In addition, lecturers also had an understanding that students with hearing impairments are limited to their senses alone not in their cognitive abilities.

\section{B. Affective Aspect}

In the affective aspect, the lecturers believed that the ability of students with hearing impairments and were optimistic that what is given is also acceptable to students with hearing impairments. This is evidenced by the lack of special privileges given by lecturers during the learning and assignments given. Students still play a role in the classroom, as well as at the time of presentation of the students with hearing impairments still that they have the opportunity to go to the front of the class and explain the group's material using sign language.

During the teaching and learning processes, the lecturers did not feel awkward with the presence of students with hearing impairments in the classroom. Even though the lecturer cannot speak sign language; however, through everyday body language, the lecturers believed that there is a meaning conveyed through the material presented. In addition, the presence of volunteers who assisted them also reduces the sense of worry over student acceptance with hearing barriers to the material presented. Nevertheless, there was one lecturer who evaluated the course by asking the success of lectures for students with hearing impairments. As for the results of the evaluation of 8 students with special needs, there was only 1 student stated that the lecture activities carried out successfully. The subject taught was English. Given the hearing obstacles experienced by students, it also affects the ability to speak especially in written language.

As for the presence of volunteers who assist in the classroom, the lecturers were greatly assisted by the mentoring process during the lecture, in terms of material delivery, work assignments, and course tests. This is evident that the subject lecturers always look for the presence of volunteers before the lecture begins.

\section{Conative Aspect}

Based on the attitudes and actions taken, basically, the lecturers have strived so that students with hearing impairments can still attend the lecture process. However, there were several obstacles to its application. In the course, the lecturer did not prepare truly special preparation for students with hearing impairments. This is related to general courses which are usually a large class which includes several study programs with a total of 150 students. This situation makes the lecturers unable to use various learning method. Nevertheless, there were lecturers who strive to improve their ability to deliver learning material by finding out about sign language and delivering material to students with hearing impairments.

The learning method that was applied is by demonstrations and role-playing for outside the lecture class. The method would be suitable for all students including students with hearing impairments. The learning strategy used is by using the dominant group. In its application lecturers entrust to peers to be able to help students with hearing impairments to understand the assignments given, so students with hearing impairments can still contribute despite limitations.

The media used were more dominant in audiovisual, it is related to the variety of students with special needs found in the Special Education Study Program of Universitas Lambung Mangkurat. In lecturing, the lecturers coordinate with volunteers both directly and indirectly about the subject of assignments and examinations for students with special needs. Based on the experience in the 2nd semester, examinations carried out in the multiple-choice test for English by not reducing the level of material given and the same questions with other students. Meanwhile, in the civics education course, at the end of the exam, the lecturer gave the same questions but with different numbers. This was because the question is an essay and students with hearing impairments have obstacles in stringing words so that the number of questions about students with special needs, including students with hearing impairments, get fewer questions than the other students. As for the assessment, the lecturer provided a different range of values for students with special needs. The range of values given was lower than the actual range of values. This was given as a form of appreciation and reward for the efforts made by students with special needs to fight limitations in order to get an education in college.

\section{CONCLUSION}

Based on the results of this study, it can be concluded that in general, non-special education lecturers at the Special Education Study Program, Teacher Training and Education Faculty, Universitas Lambung Mangkurat who have taught students with special needs, including hearing impaired students, they have considerable social acceptance of students with hearing impairments. However, there are several efforts that actually need understanding and direction from those who understand about children with special needs and services, in order to remain in accordance with the rules of education services for students with special needs. The efforts made are listed as follows:

- Lecturers try to find out the abilities possessed by students with special needs including students with hearing impairments;

- Lecturers do not limit the active role of students with hearing impairments in the group learning process; 
- Lecturers are trying to find ways so that lecture material can be properly conveyed to students with hearing impairments;

- Lecturers coordinate with volunteers so that the lecture process goes as it should;

- Lecturers distinguish the number of exam questions and tolerate assessment by lowering the range of assessment and subjective assessment.

To anticipate errors in the service delivery step, there are several suggestions that can be done, namely:

- Establishment of a coordination between lecturers with related parties regarding the existence of students with special needs, so that in the future they can prepare to learn according to needs;

- Providing information and debriefing for students with special needs and lecturers;

- Mentoring activities held directly by volunteers from the Special Education study program, considering that the eight students with special needs are special education study program students.

\section{REFERENCES}

[1] Republic of Indonesia. Undang-Undang Republik Indonesia Nomor 12 Tahun 2012 tentang Pendidikan Tinggi. Jakarta: Sekretariat Negara, 2012.

[2] Republic of Indonesia. Ministry of National Education of Republic of Indonesia Ministry of National Education, Peraturan Menteri Pendidikan Nasional Republik Indonesia No. 70 Tahun 2009 Tentang Pendidikan Inklusif Bagi Peserta Didik yang Memiliki Kelainan dan Memiliki Potensi Kecerdasan dan/ atau Bakat Isimewa. Jakarta: The Ministry, 2012.

[3] Republic of Indonesia. Ministry of Research, Technology, and Higher Education, Peraturan Menteri Riset, Teknologi, dan Pendidikan Tinggi Republik Indonesia No. 46 Tahun 2017 Tentang Pendidikan Khusus dan Pendidikan Layanan Khusus di Perguruan Tinggi. Jakarta: The Ministry, 2017.

[4] H. Nawawi, Metode Penelitian Bidang Sosial. Jogjakarta: Gadjah Mada University Press, 2000.

[5] J. W. Creswell, Research Design Pendekatan Kuantitatif, Kualitatif, dan Mix Method, Edisi Ketiga. Bandung: Pustaka Pelajar, 2008.

[6] U. F. Rizky, "Identifikasi Kebutuhan Siswa Penyandang Disabilitas Pasca Sekolah Menengah Atas," Indonesian Journal of Disability Studies, vol. 1, no. 1, pp. 52-59, 2014.

[7] I. Yuwono and U. Utomo, Pendidikan Inklusif Paradigma Pendidikan Ramah Anak. Banjarmasin: Pustaka Banua, 2015. 